\title{
To Check Neo-Formation of Ethyl Alcohol in Stored Blood
}

\author{
Komal Singh $^{1^{*}}$, Ritu Malik ${ }^{2}$ and Loveleen Kumar Katyal ${ }^{2}$ \\ ${ }^{1}$ Department of Zoology, Kurukshetra University, India \\ ${ }^{2}$ Assistant Director Chemistry and Toxicology Division, Forensic Science Laboratory, India
}

Submission: March 09, 2018; Published: May 09, 2018

*Corresponding author: Komal Singh, Department of Zoology, Kurukshetra University, Kurukshetra, India, Email: komalsingh338@gmail.com

\begin{abstract}
During the investigation of accidental cases, blood samples obtained from accidental victim are submitted to forensic science laboratory for toxicological analysis. All through, ethanol analysis is performed on almost all cases of blood samples. The main problem is determining alcohol concentration in these cases is changes in Blood Alcohol Concentration (BAC) that can occur due to neoformation of ethanol. Blood samples stored under insufficient conditions or for longer times and body fluids have undergone petrifaction often contains certain amount of volatile compounds. In the light of possibility that, neoformation of ethanol in improperly stored blood might give rise to an incorrect estimation of BAC. With this in mind, to study the effect of preservative and temperature on the formation and concentration of ethanol in blood samples, we estimated the ethanol neogenesis in stored and normal blood in different time period $(0,7,14,21,28,35$ and 42 days). Head Space- Gas Chromatography instrument used to measure the level of ethanol in blood sample. We found that neoformation of ethanol was observed in normal blood sample. There was no any neoformation observed in blood sample with preservative and blood stored at $4^{\circ} \mathrm{C}$. Our study is supporting the studies which suggest that storage condition will affect the neoformation of ethanol in blood samples.
\end{abstract}

Keywords: Blood Alcohol Concentration; Neoformation; Head Space-Gas Chromatography; Ethanol.

\section{Introduction}

Determination of alcohol concentration is of great importance in medico legal autopsy blood samples, regardless of whether civil, criminal, or insurance law is involved. Blood alcohol cases in living individuals is often performed in forensic practice (e.g. after traffic accidents). Medico legal problems are not confined to determining alcohol as either a sole or joint cause of death, such as in accidents, but also include the problem of distinguishing true alcoholic poisoning. It is known that alcohol can be produced in blood after sampling. The amount of generated ethanol depends on the species of microorganisms present, the available substrates, the temperature and time of storage and the presence of preservatives added to the specimens. Neogenesis means regeneration of biological tissue or the formation of new products.

Transformation and degradation of the well-known body structures (e.g. enzymatic digestion of cell components and membranes), together with accumulation of bacterial metabolites are likely to generate a huge range of new chemical compounds. Blood samples stored under insufficient conditions or for longer times and body fluids have undergone petrifaction often contains certain amounts of volatile compounds. A number of ubiquitous microorganisms are capable of forming or degrading alcohol, and neogenesis of ethanol is only a byproduct of bacterial decomposition processes. The reactions that take place are mainly influenced by temperature, $\mathrm{pH}$ value, concentrations of available carbohydrates, and the presence of other utilizable nutrients. Putrefaction or decomposition is the final stage produced mainly by the action of bacterial enzymes mostly anaerobic organisms. These destructive bacterial agents cause marked haemolysis, liquefaction of clots and fresh thrombi and emboli, disintegration of tissues and gas formation in blood. Bacteria produces a large variety of enzymes and these breakdown the various tissues of the body. There is a progressive alteration of proteins, carbohydrates and fats. Putrefaction begins mainly by reductive processes due to the action of endogenous and exogenous bacteria and their enzymes and decay, based on oxidative reactions. Body tissues remain bacteriologically sterile from exogenous infection for at least 20 hours after death. Whereas advanced putrefaction of a blood sample can be recognized macroscopically and by its odour, the transitional phase into putrefaction presents difficulties. As the blood decomposes its colouring matter transduce into the tissues which become uniformly red. The colour becomes darker and finally turns black. The most abundant volatiles detected during the forensic ethanol analysis are ethanol, acetaldehyde, 
1-propanol, 2-propanol and acetone. These volatiles could either be initiated in the human body after the consumption of alcoholic beverages; or have been produced later during metabolic processes or by microbes. Alcohol concentration often changes in putrefying blood. These changes might be caused by either a change in the level of ethanol or to the formation of higher alcohols, aldehydes and ketones. Even though "fresh" samples of blood can contain a variety of higher alcohols. Therefore, the presence of such alcohols must be a result of neogenesis within the corpse or the stored blood sample.

\section{Anticoagulants and preservatives for blood}

Anticoagulant is a substance that prevents blood from clotting by suppressing the synthesis or function of various clotting factors. The first anticoagulant preservative was introduced by Rous and Turner in 1916. It consisted of a citrateglucose solution in which blood from rabbits was stored for two weeks, which prevented anaemia when transfused in another rabbit who had suffered from blood loss. Some of the commonly used anticoagulants are:

EDTA: Ethylen Ediaminetetra Acetic Acid as disodium or potassium salts is used. This is a chelating agent which binds the calcium which is needed for coagulation. It is effective at a final concentration of 1 to $2 \mathrm{mg} / \mathrm{ml}$ of blood. More than $2 \mathrm{mg} / \mathrm{ml}$ causes shrinkage of the cells. This is the best anticoagulant for peripheral blood smear and studies.

Drawbacks: It inhibits the activities of enzymes like alkaline phosphatase, creatine kinase, and leucine aminopeptidase. EDTA is not suitable for calcium and iron estimation.

Heparin: It is mucoitin polysulfuric acid available as sodium potassium, lithium and ammonium salts. Heparin accelerate the action of antithrombin III $\longrightarrow$ - which neutralizes thrombin $\longrightarrow$ thus prevents the formation of $\longrightarrow$ fibrin from fibrinogen. Heparin is added $0.2 \mathrm{mg} / \mathrm{ml}$ of blood.

Drawback: It inhibits the acid phosphates activity. It interferes with binding of calcium to EDTA.

Oxalate: This form insoluble complex with calcium ions. Potassium oxalate at concentration of 1 to $2 \mathrm{mg} / \mathrm{ml}$ of blood is used. Combination of ammonium/potassium oxalate does not lead to shrinkage of the RBCs.

Drawbacks: If the concentration is $3 \mathrm{mg} / \mathrm{ml}$, then there are chances for hemolysis. Oxalates inhibit several enzymes like acid phosphates, alkaline phosphates, amylase, LDH, and may cause the precipitation of calcium as oxalate salt.

Sodium Fluoride: This is a weak anticoagulant but used antiglycolytic agent to preserve the glucose. This inhibits the system involved in glycolysis and preserves the glucose. This is effective at a concentration of $2 \mathrm{mg} / \mathrm{ml}$ of blood along with other anticoagulant like oxalate.

Drawback: This is also inhibitor of many enzymes and also effect urease for the estimation of urea.

\section{Effect of temperature and preservative on blood}

When blood is stored at $2-6^{\circ} \mathrm{C}$, glycosis is reduced but does not stop. Preservative solutions provide buffering capability to minimize $\mathrm{pH}$ changes and optimize the storage period. The lower temperature keeps the rate of glycolysis at lower limit and minimizes the proliferation of bacteria that might have entered the blood unit during venipuncture or from atmosphere. The rate of diffusion of electrolytes $(\mathrm{Na}+$ and $\mathrm{K}+$ ) across the cell membrane is also less at lower temperature.

Additive Solutions: One major benefit of the additive system is increase in the level of ATP, and red cells viability is enhanced, extending the shelf-life of the red cells to 42 days.

\section{Materials and Method}

Blood sample of healthy individual was collected from blood bank Sh. Narayan Hospital Rewari, Haryana.

Three flasks were taken having human blood $(60 \mathrm{ml})$ in each flask. Chemical used: (a) Sodium fluoride (as preservative), this inhibit the system involved in glycolysis and preserve the glucose (b) n-propanol (for internal standard) standards are used by which can be relate the concentration of the standard to concentration of the peak of the ethanol. Samples were analysed using instruments Head space - Gas Chromatography.

Blood samples were divided into three conical flasks.

a) With 500mg sodium fluoride (preservative) at room temperature

b) Without preservative at room temperature

c) Without preservative at cold temperature.

All three flasks were kept at their respective sites up to completion of the study from 16 February 2016 to 31 March 2016. Two vials of $1 \mathrm{ml}$ each were prepared from each conical flask. Three vials with internal standard ( $90 \mathrm{ul} / 1 \mathrm{ml}$ of blood sample) and three without internal standard. Blood was prepared for HSGC. Three vials were subjected for qualitative study and another three for the quantitative analysis. After instrumentation graph was prepared and studied (Figure $1 \&$ Table 1 ).

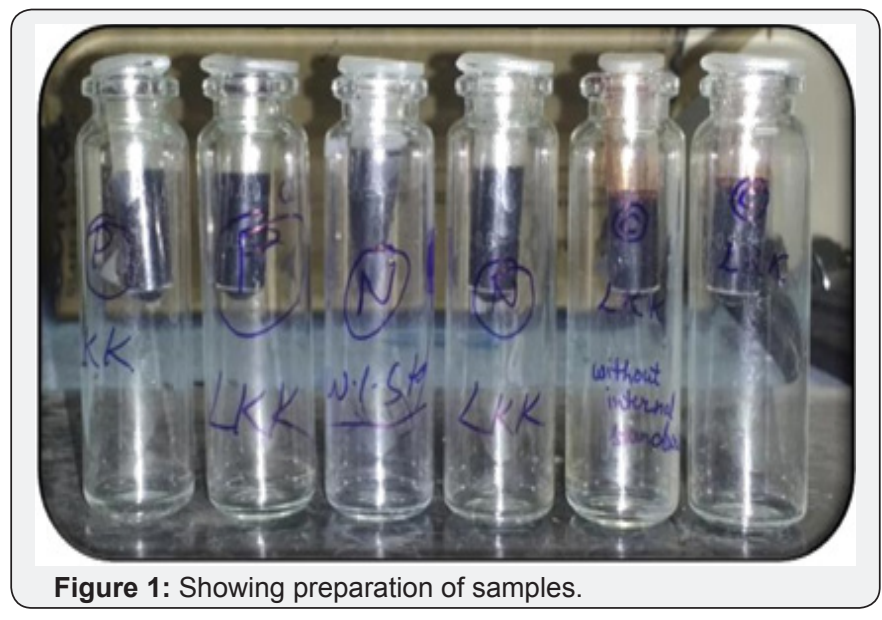


Table 1: Showing parameters of Gas Chromatography.

\begin{tabular}{|c|c|}
\hline Instrument & $\begin{array}{c}\text { Gas chromatography-Clarus } \\
\mathbf{5 0 0} \text { (Perkin Elmer) }\end{array}$ \\
\hline Column & Elite wax,30m,ID-0.32um \\
\hline Detector & FID $\left(220^{\circ} \mathrm{C}\right.$ ) \\
\hline Carrier gas & Nitrogen $(1 \mathrm{ml} / \mathrm{min})$ \\
\hline Hydrogen Rate & $40 \mathrm{ml} / \mathrm{min}$ \\
\hline Air Rate & $400 \mathrm{ml} / \mathrm{min}$ \\
\hline Injection Temperature & $180^{\circ} \mathrm{C}$ \\
\hline F.I.D Temperature & $220^{\circ} \mathrm{C}$ \\
\hline Column temperature & $45^{\circ} \mathrm{C}-220^{\circ} \mathrm{C}$ \\
\hline
\end{tabular}

Table 2: Showing parameters of Head space.

\begin{tabular}{|c|c|}
\hline Column & $\begin{array}{c}\text { 2m x 1/8" O.D. Stainless steel } \\
\text { column.W(mesh:100-120). }\end{array}$ \\
\hline Detector & F.I.D. \\
\hline Carried Gas & Nitrogen $(32$ lbs / sq. inch.) \\
\hline Needle temperature & $80^{\circ} \mathrm{C}$ \\
\hline Transfer line temperature & $130^{\circ} \mathrm{C}$ \\
\hline Oven temperature & $70^{\circ} \mathrm{C}$ \\
\hline Thermostat time & $15 \mathrm{~min}$ \\
\hline Injection time & $0.8 \mathrm{~min}$ \\
\hline Pressurization time & $0.5 \mathrm{~min}$ \\
\hline Cycle time & $19 \mathrm{~min}$ \\
\hline
\end{tabular}

Headspace GC is used for the analysis of volatile and semivolatile organics in solid, liquid and gas samples. The headspace method is especially suitable for the very fast separation of volatile components (alcohols, acetone, aldehydes) in complex biological matrices especially blood in mass-liquor and prohibition law related cases. This method has the advantage of avoiding the risk of contamination of non-volatile components, which may be eliminated due to on-line analysis by gas chromatography. The principle underlying the headspace analysis is that in a sealed vial at constant temperature, equilibrium is established between the volatile components of a liquid sample and the gas phase above it (the head space). After allowing the time for equilibrium a portion of the headspace may be withdrawn one by one from vials using a gas-tight syringe and injected to GC for on-line analysis (Table 2).

\section{Results and Discussion}

Blood samples stored under insufficient conditions or for longer times have undergone putrefaction often contains certain amounts of volatile compounds [1]. The increase of ethanol and higher alcohols in putrefying blood is often recognized, for which firstand foremostbacteria's are reasonable [2].Therefore, ethanol is only a byproduct of bacterial decomposition processes. The reactions that take place are mainly influenced by temperature, $\mathrm{pH}$ value, concentrations of available carbohydrates, and the presence of other utilizable nutrients [3].

\section{Pathway of metabolism}

Fructose-1,6-bisphosphate $\Rightarrow$ glyceraldehyde-3-phosphate $\Rightarrow$ 3 -phosphoglycerate $\Rightarrow 2$-phosphoglycerate $\Rightarrow$ phosphoenolpyruvate $\Rightarrow$ pyruvate $\Rightarrow$ acetaldehyde

Acetaldehyde + glyceraldehyde-3-phosphate + H2O $\Rightarrow$ 3-phosphoglycerate + ethanol.

Comparing blood samples will recognize that the qualitative and quantitative; concentration of alcohols can be quite different. In this study we examined the alcohol concentration qualitatively and quantitatively using head space-gas chromatography at the interval of successive seventh day from 16 Feb 2016 to 31 March 2016. The chromatogram of three different samples at different time periods is shown in following figures. Putrefaction of a blood sample was recognized by its odour and color $[4,5]$. The predominating compound of alcohol formation in anaerobic putrefaction is ethanol. Additional formation of methanol, acetone was also observed only in trace amounts [6]. But this study was only focused on the formation of Ethanol [7]. The concentration of ethyl alcohol varies. However no alcohol was detected at $4^{\circ} \mathrm{C}$. Graphs of preservative, cold, and normal condition is showing ethanol neogenesis in blood (Figure 2-12 \& Table 3).

Table 3: Showing concentration of alcohol in different samples during different time periods.

\begin{tabular}{|c|c|c|c|c|c|}
\hline Days & Date & $\begin{array}{l}\text { Changes/ } \\
\text { Compounds } \\
\text { Formed }\end{array}$ & $\begin{array}{c}\text { Sample } \\
\text { Normal (N) }\end{array}$ & $\begin{array}{c}\text { Sample } \\
\text { Preser } \\
\text { vative } \\
\text { (P) }\end{array}$ & $\begin{array}{l}\text { Sample } \\
\text { Cold (c) }\end{array}$ \\
\hline 1 & 16-Feb & Nil & No change & $\begin{array}{c}\text { No } \\
\text { change }\end{array}$ & $\begin{array}{c}\text { No } \\
\text { change }\end{array}$ \\
\hline 2 & 23-Feb & Ethanol & $\begin{array}{c}1 \mathrm{mg} / 100 \mathrm{ml} \\
\text { of blood }\end{array}$ & $\begin{array}{c}\text { No } \\
\text { change }\end{array}$ & $\begin{array}{c}\text { No } \\
\text { change }\end{array}$ \\
\hline 3 & 1-Mar & Ethanol & $\begin{array}{c}1.6 \mathrm{mg} / 100 \mathrm{ml} \\
\text { of blood }\end{array}$ & $\begin{array}{c}\text { No } \\
\text { change }\end{array}$ & $\begin{array}{c}\text { No } \\
\text { change }\end{array}$ \\
\hline 4 & 8-Mar & Ethanol & $\begin{array}{c}0.5 \mathrm{mg} / 100 \mathrm{ml} \\
\text { of blood }\end{array}$ & $\begin{array}{c}\text { No } \\
\text { change }\end{array}$ & $\begin{array}{c}\text { No } \\
\text { change }\end{array}$ \\
\hline 5 & 15-Mar & Ethanol & $\begin{array}{l}1.6 \mathrm{mg} / 100 \\
\mathrm{ml} \text { of blood }\end{array}$ & $\begin{array}{c}\text { No } \\
\text { change }\end{array}$ & $\begin{array}{c}\text { No } \\
\text { change }\end{array}$ \\
\hline 6 & 22-Mar & Ethanol & $\begin{array}{c}1.4 \mathrm{mg} / 100 \mathrm{ml} \\
\text { of blood }\end{array}$ & $\begin{array}{c}\text { No } \\
\text { change }\end{array}$ & $\begin{array}{c}\text { No } \\
\text { change }\end{array}$ \\
\hline 7 & 29-Mar & Ethanol & $\begin{array}{c}1.3 \mathrm{mg} / 100 \mathrm{ml} \\
\text { of blood }\end{array}$ & $\begin{array}{c}\text { No } \\
\text { change }\end{array}$ & $\begin{array}{c}\text { No } \\
\text { change }\end{array}$ \\
\hline
\end{tabular}



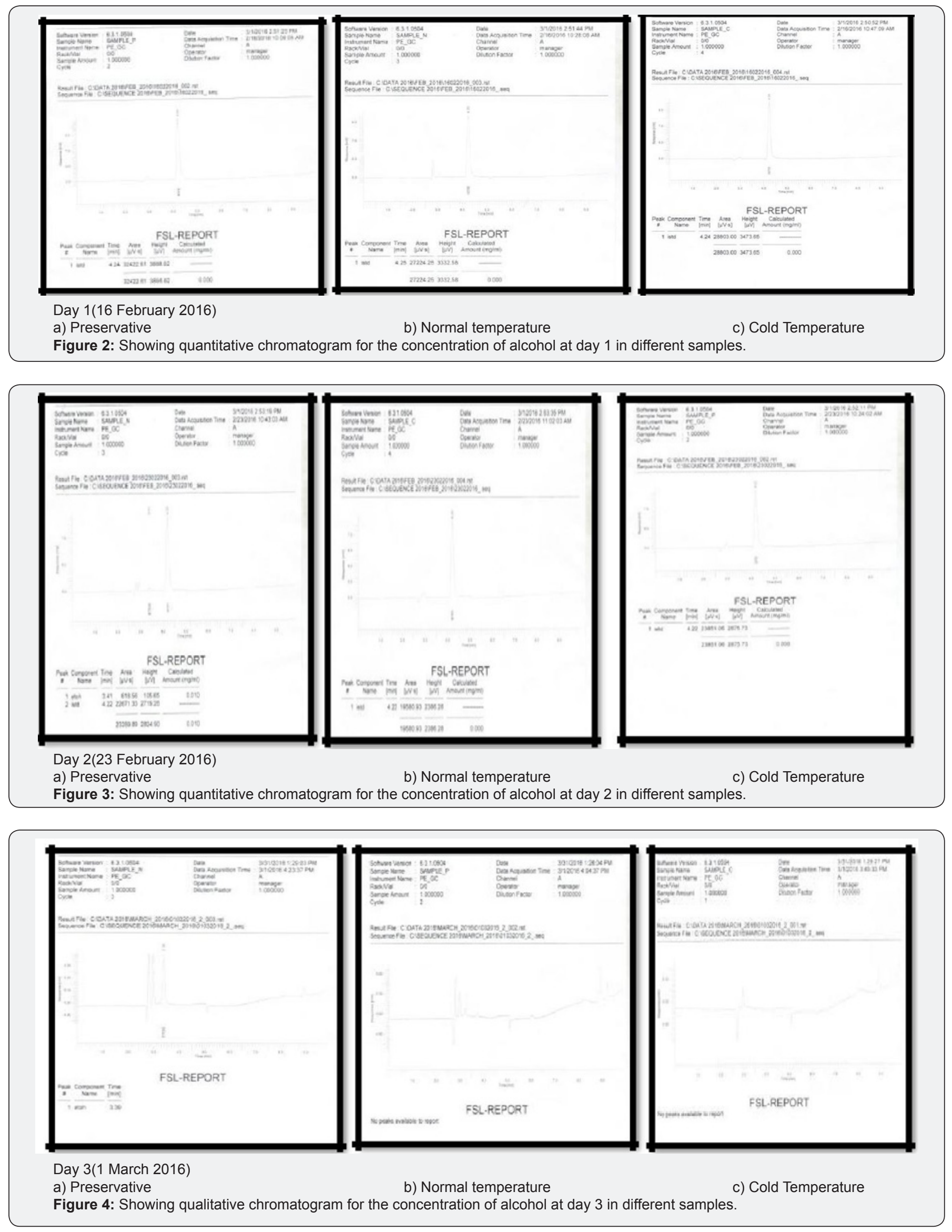

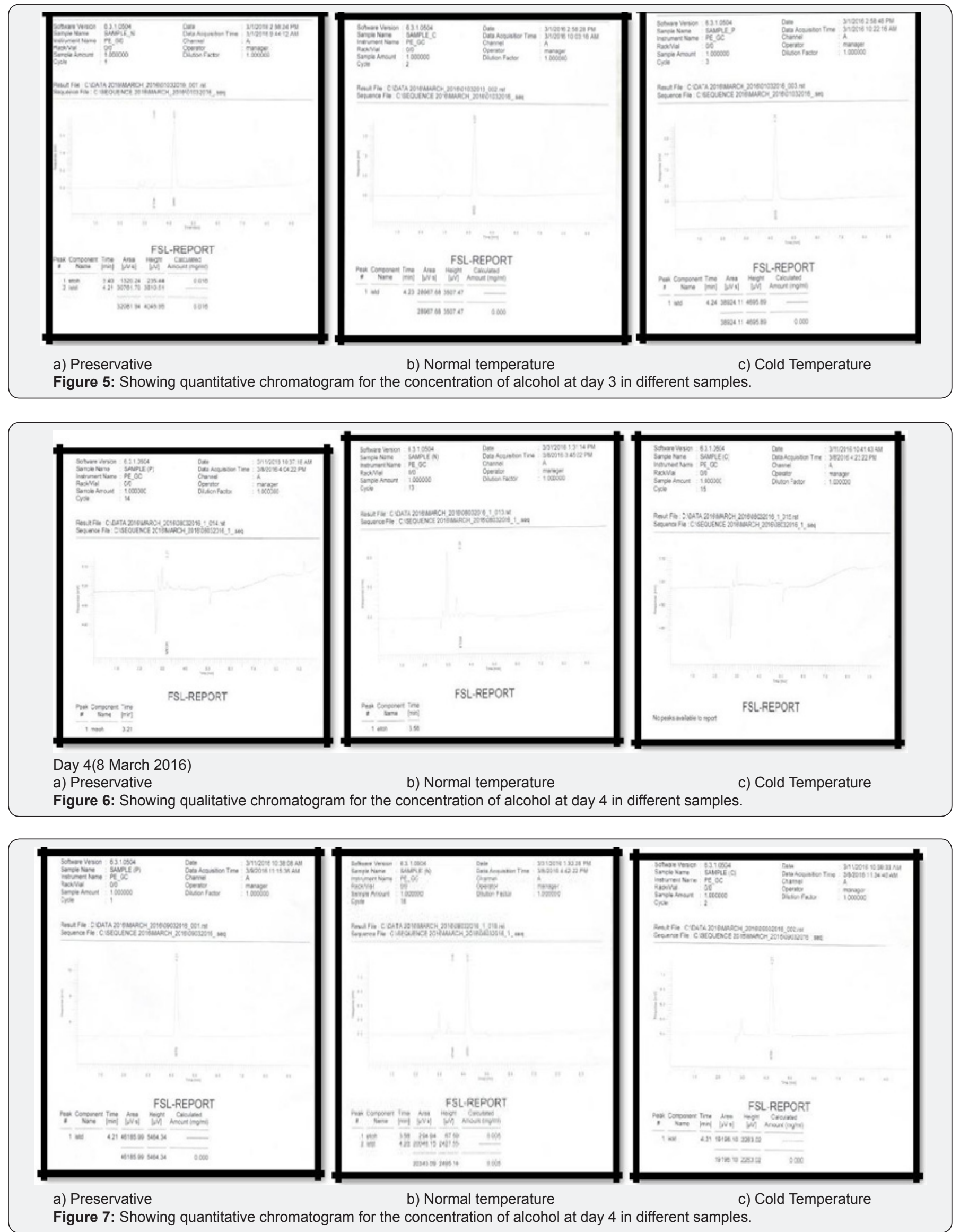

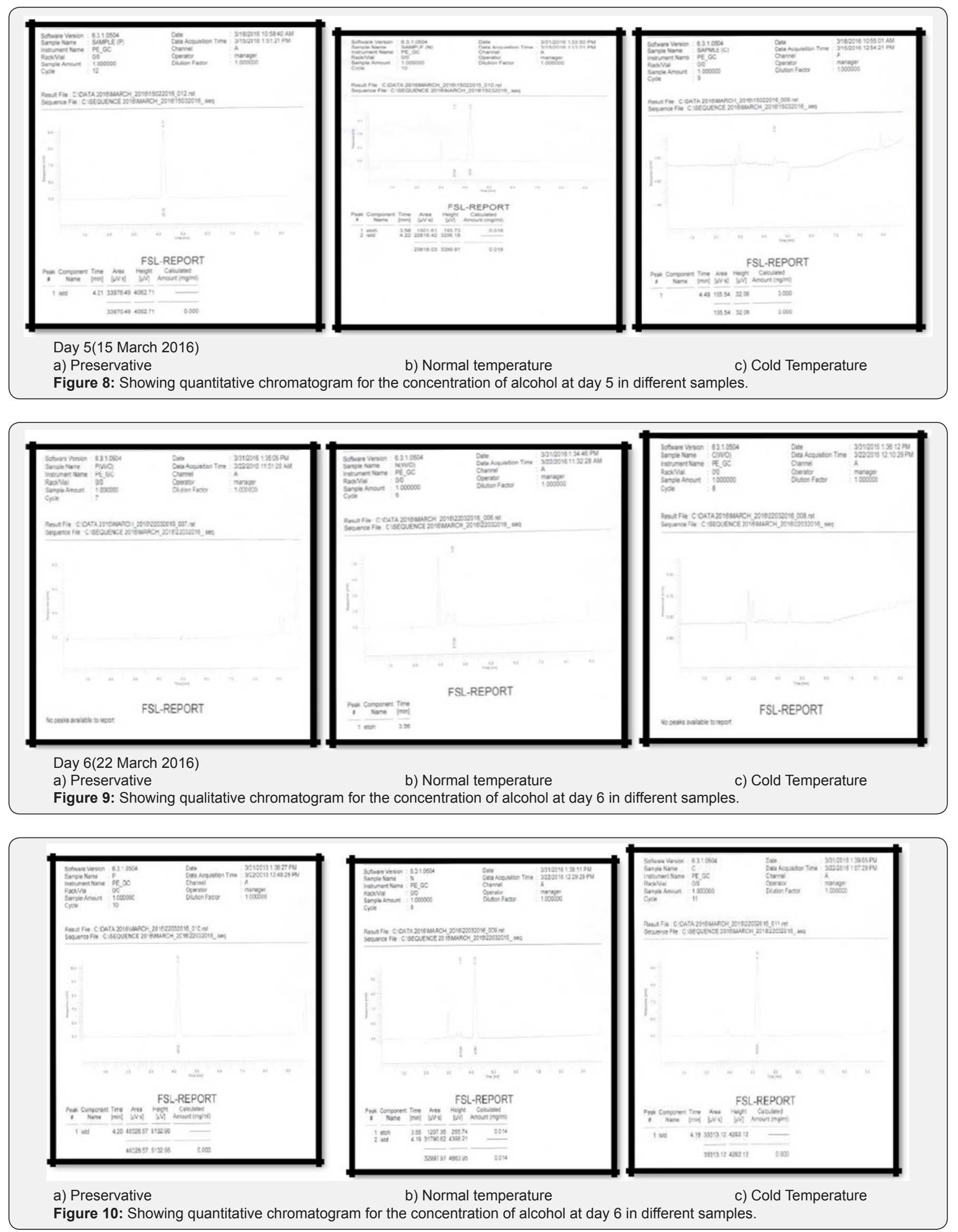


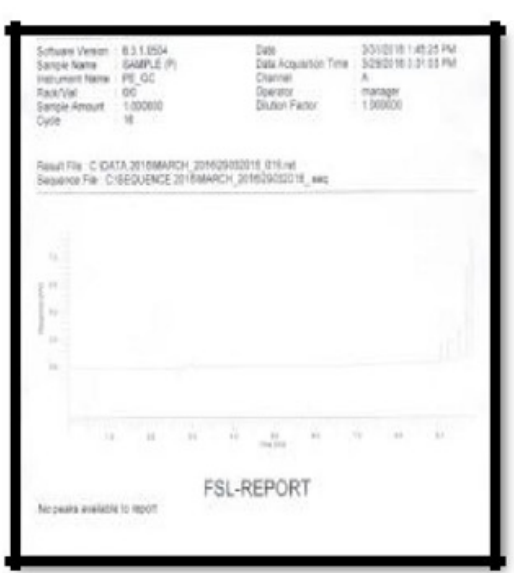

Day 7(29 March 2016)

a) Preservative

Figure 11: Showing qualitative chromatogram for the concentration of alcohol

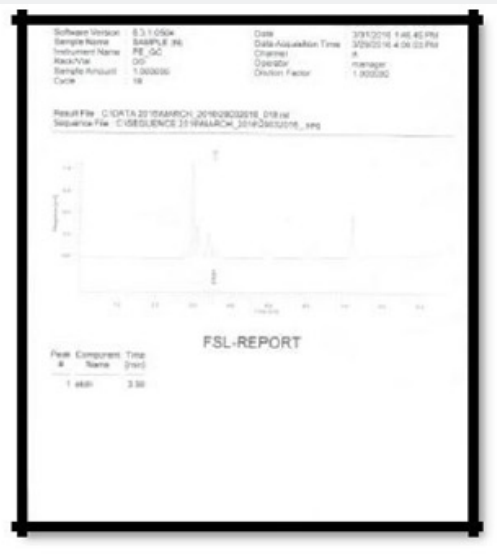

b) Normal temperature

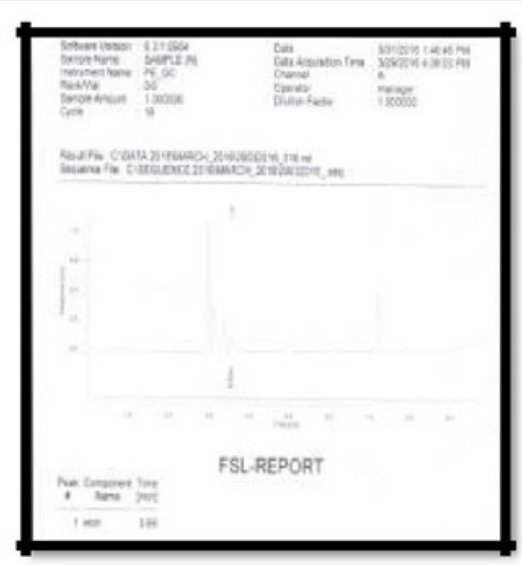

c) Cold Temperature

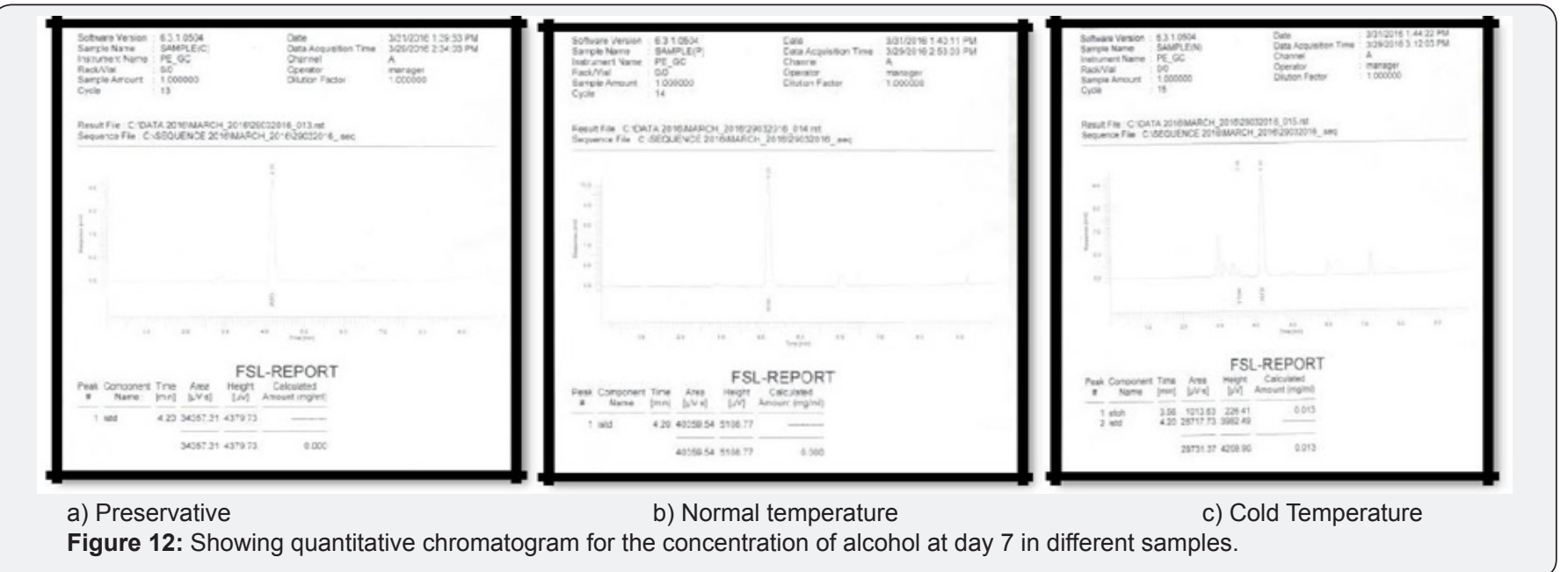

\section{Conclusion}

Neo-formation of ethanol is due to microbial action either post-mortem in the body or from improper storage or preservation of the biological samples is a common problem in forensic toxicology. Whether the victim consumed ethanol ante-mortem or whether the ethanol formed due to putrefactive processes is an important forensic issue and much research has been made into this area. Various indicators have been proposed to identify ethanol neo-formation. In this project report neo formation of ethanol has been checked by using different temperature conditions and preservative. The alcohol concentration qualitatively and quantitatively using head spacegas chromatography at the interval of successive seventh day from 16 Feb 2016 to 31 March 2016. The chromatogram of three different samples at different time periods is shown in figures given above. At normal room temperature i.e. $20-28^{\circ} \mathrm{C}$ without preservation the decomposition of the blood start (putrifaction) leads to formation of Ethyl alcohol. The concentration of ethyl alcohol varies (as shown in Table 3). However no alcohol was detected at $4^{\circ} \mathrm{C}$. It was found that the concentration of ethyl alcohol have varied pattern followed by a slight concentration decrease after $4^{\text {th }}$ day. Thereafter, ethanol concentration remains more or less constant. The interpretation of postmortem alcohol levels is still problematic in the forensic pathological setting and in the field of legal medicine.

\section{Acknowledgement}

I express my sincere and profound gratitude and deep regards to prof. Dr. R.K Sharma, Chairperson, Department of Zoology Kurukshetra University Kurukshtra for allowing me to carry out the present study. I am highly obliged to Dr. R.K Sarin, Director Forensic Science Laboratory, NewDelhi - Rohini) for giving me the opportunity to undergo training course at their estimated institute. However, it would not have been possible without the kind support and help of many individuals and organizations. I would like to extend my sincere thanks to all of them. I am highly indebted to Mr. Loveleen Kumar Katyal for their guidance, ideas and constant supervision as well as for providing necessary information regarding the project and also for their support in completing the project. I would like to express my gratitude towards Dr. Jogender Tanwar (maternal uncle) and all 
member of Forensic Science Laboratory, New Delhi (Rohini) for their kind co-operation and encouragement which help me in completion of this project. My thanks and appreciations also go to my colleague my friend Ritu Malik in developing the project and people who have willingly helped me out with their abilities.

\section{References}

1. Karon BS, van Buskirk CM, Jaben EA, Hoyer JD, Thomas DD (2012) Temporal sequence of major biochemical events during Blood Bank storage of packed red blood cells. Blood Transfus 10(4): 453-461.

2. Blackmore DJ (1968) The Bacterial Production of Ethyl Alcohol, Forensic Science Society Journal 8(2-3): 73-78.

This work is licensed under Creative Commons Attribution 4.0 License

DOI: 10.19080/OAJT.2018.03.555612
3. Chang J, Kollman SE (1989) The Effect of Temperature on the Formation of Ethanol by Candida Albicans in Blood, J Forensic Sci 34(1): 105-109.

4. Dubash J, Clegg O, Vaughan J (1940) Changes Occurring In Blood Stored In Different Preservatives. Br Med J 2(4162): 482-484.

5. JG Wigmore, BLC Chow (2000) Detection of Neo-formation of Ethanol in a Postmortem Blood Sample Using N-propanol and a Urine Sample Canadian Society of Forensic Science Journal 33(1): 145-149.

6. Kerrigan S (2013) Sampling, storage and stability. In: Negrusz A \& Cooper G (Ed.), Clarke's Analytical Forensic Toxicology. The Pharmaceutical Press, ( $\left.2^{\text {nd }} e d n\right)$, London, pp. 346-354.

7. Petković S, Savić S, Zgonjanin D, Samojlik I (2008) Ethanol concentrations in Antemortem Blood Samples Under Controlled Conditions, Alcohol Alcohol 43(6): 658-660.

\section{Your next submission with Juniper Publishers will reach you the below assets}

- Quality Editorial service

- Swift Peer Review

- Reprints availability

- E-prints Service

- Manuscript Podcast for convenient understanding

- Global attainment for your research

- Manuscript accessibility in different formats

( Pdf, E-pub, Full Text, Audio)

- Unceasing customer service

Track the below URL for one-step submission https://juniperpublishers.com/online-submission.php 